\title{
Erratum to: Do Recently Diagnosed Black Breast Cancer Patients Find Questions About Cancer Fatalism Acceptable? A Preliminary Report
}

Vanessa B. Sheppard • Kimberly Davis •

Marc Boisvert • Yvonne Jennings • Becky Montalvo

Published online: 29 August 2010

(C) Springer 2010

Erratum to: J Canc Educ

DOI 10.1007/s13187-010-0134-6

In the original publication, the third author's first name was misspelled. The correct spelling is Marc Boisvert.

The online version of the original article can be found at http://dx.doi. org/10.1007/s13187-010-0134-6.

V. B. Sheppard $(\bowtie)$

Cancer Control Program, Georgetown University,

3300 Whitehaven St., NW, Suite 4100,

Washington, DC 20007, USA

e-mail: vls3@georgetown.edu

K. Davis $\cdot$ Y. Jennings

Cancer Control Program, Georgetown University,

Washington, DC, USA

M. Boisvert · B. Montalvo

Washington Cancer Institute, Washington Hospital Center,

110 Irving St., NW, Ste. C-2149,

Washington, DC 20010, USA 